Jurnal Indonesia Sosial Teknologi: p-ISSN: 2723 - 6609

e-ISSN : 2745-5254

Vol. 2, No. 7 Juli 2021

\title{
PERTARUNGAN MODEL ALTMAN, SPRINGATE, ZMIJEWSKI DAN GROVER MEMPREDIKSI FINANCIAL DISTRESS PERUSAHAAN JASA
}

\author{
Mohamad Ismail Chandra1, Suyanto², Tri Widyastuti ${ }^{3}$, Nurmala Ahmar ${ }^{4}$ \\ ${ }^{1}$ Universitas Pancasila, Jakarta, ${ }^{2}$ Sekolah Tinggi Ilmu Ekonomi IPWI, Jakarta, \\ ${ }^{3}$ Universitas Bhayangkara Jakarta Raya, Jakarta, ${ }^{4}$ Universitas Pancasila, Jakarta \\ Email: chandraismail1307@gmail.com ${ }^{1}$, suyanto.ipwija@gmail.com ${ }^{2}$, \\ triewidhiastuti@yahoo.com ${ }^{3}$, nurmala.ahmar@univ.pancasila.co.id ${ }^{4}$
}

\begin{abstract}
Abstrak
Penelitian ini bertujuan untuk meneliti model prediksi financial distress terbaik diantara 4 model yaitu Altman Z Score, Springate, Zmijewski, dan Grover dalam memprediksi financial distress pada perusahaan jasa pada sub sektor investasi dan sekuritas yang terdaftar di Bursa Efek Indonesia periode 2012-2016. Sampel yang digunakan dalam penelitian ini sebanyak 16 perusahaan jasa sub sektor sekuritas dan investasi di Bursa Efek Indonesia. Tehnik sampling yang digunakan dalam penelitian ini adalah purposive sampling yaitu salah satu tehnik non random dimana peneliti menentukan pengambilan sample dengan cara menetapkan ciri-ciri khusus yang sesuai dengan tujuan penelitian. Hasil Penelitian menunjukan bahwa terdapat perbedaan hasil prediksi financial distress antara model Altman Z Score, Springate, Zmijewski, dan Grover dalam memprediksi financial distress. Model Grover merupakan model terbaik, kemampuan variabel independen secara bersama-sama dalam mempengaruhi variabel dependen juga cukup baik, dari 3 variabel yang digunakan, semua variabel berpengaruh positif terhadap financial distress. Model Grover juga yang paling rendah memprediksi perusahaan yang distress baik melalui uji deskriptif crosstab maupun non parametrik sesuai dengan kondisi real yang ada dimana perusahaan jasa studi kasus (sub sektor investasi dan sekuritas) yang terdaftar di Bursa Efek Indonesia yang dijadikan sample penelitian tersebut sampai dengan tahun 2016 tidak ada yang distress dan baru pada tahun 2018 ada 1 (satu) perusahaan yang di suspend.
\end{abstract}

Kata Kunci: skor altman Z; pegas; zmijewski; grover dan kesulitan keuangan

\section{Abstract}

This study aims to examine the best financial distress prediction models among 4 models ie Altman Z Score, Springate, Zmijewski, and Grover in predicting financial distress at the company services in the investment and securities sub-sector listed on the Indonesia Stock Exchange for the period 2012-2016. The samples used in this study were as many as 16 companies services securities and investment subsector on the Indonesia Stock Exchange. The data analysis technique used in this study was purposive sampling technique. The results showed that there were differences in the prediction results of financial distress between the Altman $Z$ Score, Springate, Zmijewski, and Grover models. in predicting financial distress. Grover's model is the best model, the ability of the independent variables together 
to influence the dependent variable is also quite good, of the 3 variables used, all variables have a positive effect on financial distress. The Grover model is also the lowest predictor of companies that are distressed both through crosstab and nonparametric descriptive tests according to the existing real conditions where the company case study services (investment and securities sub-sector) listed on the Indonesia Stock Exchange which were used as research samples until 2016 had no distress and only in 2018 there was 1 (one) company that was suspended.

Keywords: altman Z score; springate; zmijewski; grover and financial distress

\section{Pendahuluan}

Pelaku usaha berperan besar dalam menopang pertumbuhan ekonomi serta kinerja pemerintahan khususnya bidang pembagunan dan ekonomi. "Tingginya pertumbuhan ekonomi akan mampu meningkatkan tingkat kesejahteraan dan tingkat pendidikan dan pada akhirnya akan mampu memperbaiki citra dan mutu hidup" (Tambunan, Elisabet. "Modul Ajar Teori Ekonomi Makro". www.manajemen.sarimutiara.ac.id. Diakses pada 01 Januari 2018). Setiap perusahaan didirikan dengan harapan akan menghasilkan profit sehingga mampu untuk bertahan dan berkembang dalam jangka panjang dan tidak mengalami likuidasi (Aprillianto, Wulandari, \& Kurrohman, 2014). Kenyataannya, asumsi tersebut tidak selalu terjadi dengan baik dan sesuai harapan. Seringkali perusahaan yang telah beroperasi dalam jangka waktu tertentu terpaksa bubar karena mengalami kesulitan keuangan (financial distress) yang berujung pada kebangkrutan.

Financial Distress adalah keadaan kesulitan keuangan atau likuiditas yang mungkin merupakan awal terjadinya kebangkrutan. Menurut Gamayuni terdapat 5 (lima) bentuk financial distress atau kesulitan keuangan diantaranya yaitu sebagai berikut :

a. Economic failure, yaitu dimana suatu keadaan pendapatan perusahaan tidak dapat menutup total biaya perusahaan, termasuk biaya modal.

b. Business failure, yaitu dimana suatu keadaaan perusahaan menghentikan kegiatan operasional dengan tujuan mengurangi (akibat) kerugian bagi kreditor.

c. Technical insolvency, yaitu dimana suatu keadaan perusahaan tidak mampu memenuhi kewajiban yang jatuh tempo.

d. Insolvency in bankruptcy, yaitu dimana suatu keadaan nilai buku dari total kewajiban melebihi nilai pasar asset perusahaan .

e. Legal bankcruptcy, yaitu dimana suatu keadaan perusahaan dikatakan bangkrut secara hukum.

Beberapa penyebab terjadinya kesulitan keuangan bagi usaha kecil diantaranya struktur permodalan yang kurang diantaranya, menggunakan peralatan dan metode bisnis yang ketinggalan jaman, ketiadaan perencanaan, dan kualifikasi pribadi. Kualifikasi pribadi yang dimaksud adalah yaitu kurangnya pengetahuan bisnis, tidak 
ingin bekerja terlalu keras, tidak ingin mendelegasikan tugas dan wewenang, ketidakmampuan memelihara hubungan baik dengan konsumen.

Perusahaan jasa adalah suatu perusahaan yang kegiatan usahanya ditujukan untuk memperoleh pendapatan ataupun penghasilan melalui pelayanan jasa-jasa tertentu. Perusahaan jasa merupakan suatu tempat berlangsungnya proses produksi yang menggabungkan faktor-faktor produksi untuk menghasilkan suatu jasa (Ramadhani \& Lukviarman, 2009). Jasa tidak dapat dilihat, dirasa, diraba, didengar, atau dicium sebelum jasa itu dibeli. Jasa tidak mengenal persediaan atau penyimpanan produk yang telah dihasilkan. Jasa dihasilkan dan dikomsusi secara bersamaan.

Pada perkembangan dunia usaha yang pesat khususnya perusahaan di bidang jasa, semakin banyak masalah-masalah yang dihadapi oleh pemimpin perusahaan ataupun pihak manajemen. Oleh karena itu, memungkinkan seseorang pemimpin mengawasi seluruh jalannya operasional perusahaan secara langsung dan terus menerus, agar pihak manajemen perusahaan dapat melakukan tugasnya dengan baik serta mewujudkan sistem informasi yang dapat bekerja untuk mencapai tujuan memperoleh keuntungan dan dapat memuaskan kebutuhan masyarakat. Maka dengan didirikannya sebuah perusahaan tujuannya bukanlah untuk mengalami kebangkrutan melainkan berorientasi untuk kelangsungan usahanya dimasa yang akan datang sebagai prinsip utama dari mendirikan perusahaan, yaitu untuk dapat melakukan usahanya secara terus menerus (going concern). Oleh karena itu, penting bagi perusahaan untuk mengevaluasi dan mempertahankan kinerja keuangan agar perusahaan terhindar dari kegagalan usaha. Kegagalan usaha sendiri merupakan sesuatu yang sebenarnya bisa diprediksi dengan menggunakan berbagai pendekatan teori ilmu keuangan. Berikut ini adalah grafik perkembangan kebangkrutan perusahaan jasa selama 8 (delapan) tahun terakhir:

\section{Gambar 1.1}

\section{Perkembangan Kebangkrutan Perusahaan Jasa Tahun 2009-2016}

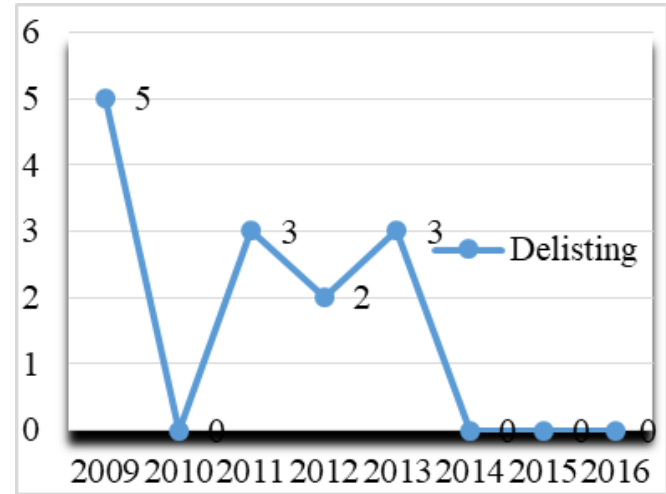

Sumber : Indonesia Capital Market Directory 2009-2016

Berdasarkan gambar 1.1 dapat dinyatakan bahwa perkembangan perusahaan jasa yang delisting dari tahun 2009-2016 tercatat BEI telah mengeluarkan 13 emiten. Dimana pada tahun 2009 sebanyak 5 emiten yaitu PT. Singer Indonesia Tbk (SING), PT. Courts Indonesia (MACO), PT. Jasa Angkasa Semesta (JASS), PT. Bukaka Teknik Utama Tbk (BUKK), dan PT. Infoasia Teknologi Global Tbk (IATG) yang telah di 
delisting dan tahun 2010 tidak terdapat perusahaan delisting oleh BEI sedangkan pada tahun 2011 BEI kembali melakukan delisting sebanyak 3 emiten yaitu PT. New Century Development, Tbk (PTRA), PT. Anta Express Tour and Travel Services, Tbk (ANTA) dan PT. Alfa Retailindo, Tbk (ALFA) . Pada tahun 2012 sebanyak 2 emiten yaitu PT. Katarina Utama,Tbk (RINA) dan PT Suryainti Permata, Tbk (SIIP), tahun 2013 terdapat 3 emiten yaitu PT. Panca Wirasakti Tbk (PWSI), Indosiar Karya Media, Tbk (IDKM) dan Amstelci Indonesia Tbk (INCF) tahun 2014, 2015 dan 2016 tidak ada perusahaan jasa yang delisting.

Munculnya berbagai model prediksi kebangkrutan merupakan antisipasi dan sistem peringatan dini terhadap kebangkrutan karena model tersebut dapat digunakan sebagai sarana untuk mengidentifikasikan bahkan memperbaiki kondisi sebelum sampai pada krisis atau kebangkrutan.

Berkaitan dengan upaya melihat aspek keuangan dan resiko yang memadai dalam industri Jasa, diperlukan suatu indikator untuk melihat tingkat kesehatan dan kinerja perusahaan yang digunakan untuk membuat prediksi apakah sebuah perusahaan memiliki potensi untuk bangkrut atau tidak. Salah satu cara untuk melihat kondisi keuangan dan kinerja perusahaan kinerja yaitu dengan menggunakan rasio keuangan, (Van Horne \& Wachowicz, 2021). Beberapa penelitian telah dilakukan untuk memprediksi potensi kebangkrutan dengan menggunakan rasio keuangan dalam menganalisis tingkat kesehatan, misalnya : (Fatmawati, 2012) yang menyatakan bahwa model Zmijewski merupakan model prediksi yang lebih akurat daripada model Altman Z-Score dan model Springate, (Prihanthini \& Sari, 2013) menyatakan bahwa model Grover paling akurat dibandingkan dengan model Springate, Zmijewski dan model Altman Z-Score, (Purnajaya \& Merkusiwati, 2014) menyatakan bahwa model Altman Z- Score dan model Zmijewski paling akurat dibandingkan dengan model Springate, (Wulandari, n.d.) menyatakan bahwa model Zmijewski dan Grover paling akurat dibandingkan dengan model Springate, Nurchayati menyatakan bahwa model Zmijewski lebih akurat dibandingkan dengan Altman Z-Score dan Springate, (Armini \& Wirama, 2015) menyatakan bahwa model Altman Z-Score akurasinya sangat tinggi (95\%), (Sayyidah \& Saifi, 2017) menyatakan bahwa Altman Z Score tingkat akurasinya lebih tinggi apabila dibandingkan dengan Springate, Zmijewski dan Grover, (Aprillianto et al., 2014) menyatakan bahwa model Altman Z-Score tingkat akurasinya lebih tinggi dibandingkan dengan Springate dan Zmijewski, Marcelinda, (Marcelinda, 2014) menyatakan bahwa model Altman Z-Score tingkat akurasinya sangat rendah (27,9\%), (Kusdiana, 2014) menyatakan bahwa model Altman Z-Score tingkat akurasinya sangat tinggi (100\%), Yami dan Pratiwi menyatakan bahwa tingkat akurasi model Zmijewski lebih tinggi dibandingkan Springate dan Z-Score, (Chrisnawan \& Norita, 2017) menyatakan bahwa tingkat akurasi model Z-Score lebih baik dari Springate dan Zmijewski, (HARTONO, 2014) menyatakan bahwa tingkat akurasi model Springate lebih tinggi dibandingkan dengan Zmijewski dan Z-Score, Rahmadini menyatakan bahwa tingkat akurasi model Z-Score dan Springate sama-sama rendah hanya $20 \%$, (KARTIKA \& Purnamasari, 2016) menyatakan bahwa tingkat akurasi model Z-Score 
lebih tinggi dibandingkan dengan model Springate dan Zmijewski. Dari hasil penelitian tersebut menunjukkan bahwa rasio keuangan bermanfaat dalam menilai kondisi kesehatan perusahaan, bahkan bermanfaat dalam memprediksi kebangkrutan perusahaan. Informasi kesehatan dan prediksi kebangkrutan sangat penting, oleh karena itu penelitian ini perlu dilakukan.

Penelitian ini mencoba menguji teori yang dihasilkan oleh Altman (1968), Springate (1978), Zmijewski (1983) serta model Grover yang diciptakan melalui penilaian dan pendesainan ulang terhadap model Altman. Altman menggunakan lima rasio, Springate (1978) dengan mengunakan empat rasio, Zmijewski (1983) menggunakan teori yang berbeda, yaitu bahwa profitabilitas, volatilitas, dan kondisi leverage perusahaan sebagai variabel terpenting dalam memprediksi distress sedangkan Model Grover menggunakan tiga rasio, teori ini bisa disamakan dengan teori liquidity, profitability, dan wealth. Berdasarkan pada penelitian terdahulu terdapat perbedaan tingkat akurasi dalam memprediksi Financial Distress. Diketahui bahwa Model Almant Z-Score paling sering digunakan dalam memprediksi Financial Distress kemudian Springate, Zmijewski dan yang terakhir Grover akan tetapi jika dilihat dari rata-rata tingkat akurasi model Grover paling tinggi dalam memprediksi Financial Distress. Kebaruan dari penelitian ini adalah sebagai berikut ;

a. Perbedaan tingkat akurasi dalam penelitian terdahulu dalam memprediksi financial distress

b. Belum ada penelitian sebelumnya analisis prediksi financial distress pada perusahaan jasa studi kasus sub sektor investasi dan sekuritas yang terdaftar di BEI

c. Pengolahan data kedalam analisis uji statistik deskriptif dgn cara crosstabulation status financial distress per tahun per model dan .deskripsi variabel dan komponen variabel dengan one way anova

d. Pengolahan data kedalam uji beda statistik non parametrik

\section{Metode Penelitian}

Sampel dalam penelitian ini adalah perusahaan publik kelompok perusahaan investasi dan sekuritas yang terdaftar di Bursa Efek Indonesia (BEI). Sesuai dengan publikasi idx.go.id menunjukkan bahwa jumlah perusahaan yang terdaftar pada periode 2012-2016 sejumlah 17 emiten atau sejumlah 85 data tahun.

Pada penelitian ini melibatkan 2 variabel, yaitu variabel dependen dan variabel independen. Variable yang digunakan dalam penelitian ini adalah financial distress sebagai variable dependen. Rasio prediksi kebangkrutan yang digunakan pada model Altman, Springate, Zmijewski dan Grover sebagai variable independen. Metode dalam mengukur masing-masing model prediksi financial distress adalah sebagai berikut.

Metode Z-Score (Altman) adalah skor yang ditentukan dari hitungan standar kali nisbah-nisbah keuangan yang akan menunjukkan tingkat kemungkinan kebangkrutan perusahaan.

$$
Z=6,56 X_{1}+3,26 X_{2}+6,72 X_{3}+1,05 X_{4}
$$


$\mathrm{X}_{1}=$ Rasio modal kerja terhadap total aktiva (WCTA)

$\mathrm{X}_{2}=$ Rasio laba ditahan terhadap total aktiva (RETA)

$\mathrm{X}_{3}=$ Rasio earning before interest and taxes terhadap total aktiva (EBITTA)

$\mathrm{X}_{4}=$ Rasio modal sendiri terhadap total utang (MVETL)

Model Springate adalah model rasio yang menggunakan multiple discriminat analysis (MDA). Dalam metode MDA diperlukan lebih dari satu rasio keuangan yang berkaitan dengan kebangkrutan perusahaan untuk membentuk suatu model yang baik. Untuk menentukan rasio-rasio mana saja yang dapat mendeteksi kemungkinan kebangkrutan, Springate menggunakan MDA untuk memililh 4 rasio dari 19 rasio keuangan yang populer dalam literatur-literatur, yang mampu membedakan secara terbaik antara sound business yang pailit dan tidak pailit. (Adnan \& Arisudhana, 2017)

$$
\begin{aligned}
& \mathrm{S}=1,03 \mathrm{X} 1+3,07 \mathrm{X} 2+0,66 \mathrm{X} 3+0,4 \mathrm{X} 4 \\
& \mathrm{X}_{1}=\text { Working Capital } / \text { Total Assets (WCTA) } \\
& \mathrm{X}_{2}=\text { Net Profit Before Interest Taxes / Total Assets (EBITTA) } \\
& \mathrm{X}_{3}=\text { Net Profit Before Taxes / Current Liability (EBTCL) } \\
& \mathrm{X}_{4}=\text { Sales / Total Assets (STA) }
\end{aligned}
$$

Model Grover adalah pendesainan dan penilaian ulang terhadap model Altman Z-Score. Jeffrey S. Grover menggunakan sampel sesuai dengan model Altman Z-score pada tahun 1968, dengan menambahkan tiga belas rasio keuangan baru (Prihanthini \& Sari, 2013).

$$
\begin{aligned}
& \mathrm{G}=1,650 \mathrm{X}_{1}+3,404 \mathrm{X}_{2}-0,016 \mathrm{X}_{3} \\
& \mathrm{X}_{1}=\text { Working Capital / Total Assets (WCTA) } \\
& \mathrm{X}_{2}=\text { Earnings Before Interest and Taxes / Total Asset (EBITTA) } \\
& \mathrm{X}_{3}=\text { Net Income / Total Assets (NITA) }
\end{aligned}
$$

Model Zmijewski menggunakan analisis rasio yang mengukur kinerja, leverage dan likuiditas perusahaan. Model ini menekankan pada jumlah hutang sebagai komponen yang paling berpengaruh terhadap kebangkrutan (Rudianto, 2013).

$$
\begin{aligned}
& \mathrm{Zm}=-4,3-4,5 \mathrm{X}_{1}+5,7 \mathrm{X}_{2}-0,004 \mathrm{X}_{3} \\
& \mathrm{X}_{1}=\text { Earning after Taxes } / \text { Total Assets (ROA) } \\
& \mathrm{X}_{2}=\text { Total Debt / Total Assets (DR) } \\
& \mathrm{X}_{3}=\text { Current Asset / Current Liabilities (CR) }
\end{aligned}
$$

Menghitung metode financial distress yang akan digunakan dari setiap kategori populasi sasaran. Untuk menilai apakah perusahaan mengalami tidak distress atau 
distress dimasa mendatang. Metode financial distress dihitung dengan cara memasukan rasio-rasio keuangan yang telah dihitung sebelumnya kedalam perhitungan di setiap metode. Adapun status 4 macam metode financial distress yang menunjukkan perusahaan tidak distress atau distress adalah sebagai berikut ;

1. Altman , didasarkan pada $Z$-score. Jika $Z<1,81$ maka perusahaan distress. Jika $1,81<\mathrm{Z}<2,99$ maka termasuk grey area (tidak dapat ditentukan apakah perusahaan sehat atau bangkrut). Jika $Z>2,99$ maka termasuk perusahaan tidak distress.

2. Springate, perusahaan yang tidak distress dan distress didasarkan pada nilai $S$ score. Jika skor $\mathrm{S}>0,862$ maka perusahaan tidak berpotensi distress. Jika skor $\mathrm{S}$ $<0,862$ maka perusahaan tidak sehat atau distress.

3. Zmijewski, perusahaan yang tidak distress dan distress didasarkan pada nilai $X$ score. Jika nilai $\mathrm{X}>0$, maka perusahaan diprediksi berpotensi mengalami distress. Jika $\mathrm{X}<0$, maka perusahaan diprediksi tidak distress.

4. Grover, perusahaan yang tidak distress dan distress didasarkan pada nilai Gscore. Jika skor $\mathrm{G} \leq-0,02$ maka perusahaan yang diprediksi mengalami distress, sedangkan bila $\mathrm{G} \geq 0,01$, maka perusahaan tidak distress.

Penelitian ini dilakukan untuk membuktikan beberapa metode dalam prediksi financial distress. Penelitian ini dilakukan dengan menggunakan data populasi Perusahaan yang masuk dalam kategori Perusahaan sub sektor jasa di Bursa Efek Indonesia yang telah mepublikasikan laporan keuangan tahunannya.

Berdasarkan tujuan yang ingin dicapai, metode yang digunakan dalam penelitian menggunakan metode statistik deskriptif. Perusahaan yang masuk kelompok perusahaan jasa selanjutnya menganalisis metode Altman Z-Score, Springate, Zmijewski dan Grover yang dapat memberikan peringatan dini kepada Perusahaan satu atau dua tahun sebelum terjadinya kondisi financial distress

Tehnik analisis dalam pengolahan data:

a. Mengumpulkan data, data yang digunakan pada penelitian ini adalah laporan keuangan perusahaan jasa (sub sektor investasi dan sekuritas) yang terdaftar di Bursa Efek Indonesia (BEI). Data laporan keuangan perusahaan tersebut dikumpulkan selama periode lima tahun

b. Menghitung Rasio Keuangan, rasio-rasio keuangan dihitung terhadap seluruh data yang ada di dalam komponenperhitungan model prediksi financial distress Altman, Springate, Zmijewski, dan Grover. Perhitungan rasio keuangan ini merupakan tahap awal penentuan score atau nilai akhir perusahaan dari tiap model prediksi financial distress. Rasio keuangan yang digunakan pada metode Altman, Springate, Zmijewski dan Grover

c. Menghitung metode financial distress yang akan digunakan dari setiap kategori populasi sasaran. Untuk menilai apakah perusahaan mengalami tidak distress atau distress dimasa mendatang. Metode financial distress dihitung dengan cara memasukan rasio-rasio keuangan yang telah dihitung sebelumnya kedalam perhitungan di setiap metode. Adapun status 4 macam 
metode financial distress yang menunjukkan perusahaan tidak distress atau distress

d. Membuat tabel status masing-masing metode financial distress, setelah dilakukannya perhitungan financial distress tahun 2012, 2013, 2014, 2015 dan 2016 dari setiap metode. Kemudian membuat tabel setiap metode hasil perhitungan financial distress; metode Altman, Springate, Zmijewski dan Grover beserta data masing-masing variabel dari metode tersebut.

e. Mengolah data kedalam analisis uji statistik deskriptif

Statistik deskrptif dilakukan dengan beberapa cara:

1) Crosstabulation status financial distress per tahun per model

2) Deskripsi variabel dan komponen variabel dengan one way anova

f. Membuat tabel excel 4 status metode financial distress

g. Mengolah data kedalam uji beda statistik Non Parametrik

h. Menarik kesimpulan

\section{Hasil dan Pembahasan}

Perbandingan model prediksi financial distress dilakukan untuk menjawab Hipotesis kelima (H5) yaitu "model terbaik yang dapat digunakan untuk memprediksi financial distress pada perusahaan jasa sub sektor investasi dan sekuritas yang terdaftar di Bursa Efek Indonesia periode 2012 - 2016".

Pada tabel 4.19 akan menyajikan perbandingan dari masing-masing mode prediksi financial distress.

Tabel 4.19

\section{Perbandingan Model Prediksi Financial Distress 1}

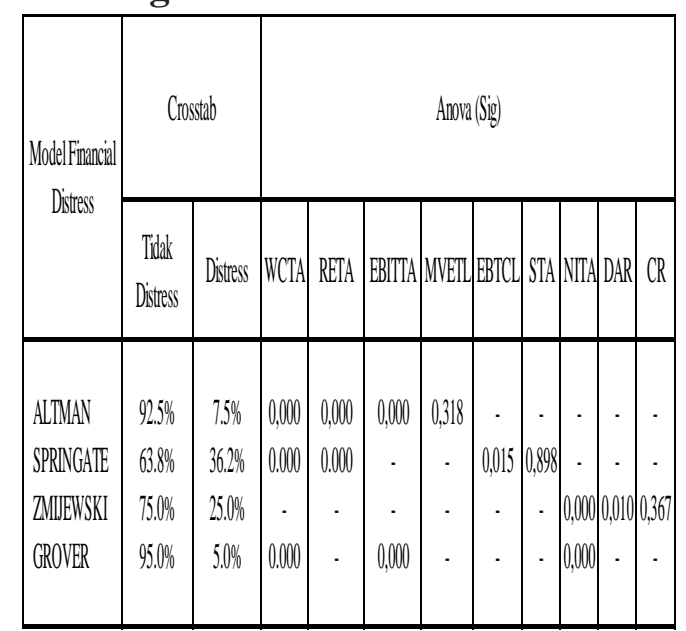

Sumber: Data diolah, 2018

Berdasarkan tabel 4.19 yang disajikan dapat dijelaskan bahwa melihat dari hasil Uji statistik deskriptif crosstab terlihat prosentase "Tidak Distress" secara berurutan yang paling besar Grover, Altman, Zmijewski dan Springate. 
Dari hasil analisis diatas tersebut terlihat tingkat akurasi prediksi financial distress model Grover memiliki tingkat akurasi yang paling baik karena ketiga variabel independennya berpengaruh signifikan terhadap financial distress dibanding dengan model Altman, Springate dan Zmijewski yang tidak semua variabel independennya berpengaruh signifikan terhadap financial distress.

Tabel 4.20

\section{Perbandingan Model Prediksi Financial Distress 2}

\begin{tabular}{|c|c|c|c|c|}
\hline \multirow{3}{*}{ Uji Statistik } & \multirow{3}{*}{$\begin{array}{c}\text { Friedman } \\
\text { (Ranks) }\end{array}$} & \multicolumn{2}{|c|}{ Cohran } & \multirow{3}{*}{$\begin{array}{c}\text { Kendall's W } \\
\text { (Ranks) }\end{array}$} \\
\hline & & \multicolumn{2}{|c|}{ Value } & \\
\hline & & 0 & 1 & \\
\hline ST-ZSCORE & 2.28 & 74 & 6 & 2.28 \\
\hline ST-SPRINGATE & 2.86 & 51 & 29 & 2.86 \\
\hline ST-ZMIJEWSKI & 2.63 & 60 & 20 & 2.63 \\
\hline ST-GROVER & 2.23 & 76 & 4 & 2.23 \\
\hline $\mathrm{N}$ & 80 & \multicolumn{2}{|c|}{80} & 80 \\
\hline CHI-SQUARE & 52.299 & \multicolumn{2}{|c|}{52.299} & 52.299 \\
\hline DF & 3 & \multicolumn{2}{|c|}{3} & 3 \\
\hline ASYMP.SIG & 0.000 & \multicolumn{2}{|c|}{0.000} & 0.000 \\
\hline
\end{tabular}

Sumber: Data diolah, 2018

Berdasarkan tabel 4.20 diatas yang disajikan dapat dijelaskan bahwa melihat dari hasil uji statistik Friedman terlihat status ranking rata-rata tertinggi yang menyatakan distress secara berurutan adalah model Springate, Zmijewski, Altman dan terakhir Grover. Terlihat juga output test statistic pada tabel diatas dimana jumlah sample 80, nilai Chi Squre hitung sebesar 52.299, df (derajat kebebasan) sebesar 3 dan asymp sig 0.000 sehingga didapatkan nilai Chi Square Tabel adalah sebesar 7.815 , karena nilai Chi Square Hitung > Chi Squre Tabel, maka Ho ditolak dan Ha diterima atau dengan kata lain ada perbedaan ranking rata-rata status model financial distress pada keempat kelompok waktu pengukuran.

Uji statistik Cohran pada tabel 4.20 diatas terlihat model financial distress dengan frekwensi tertinggi yang menyatakan distress (value = 1) secara berurutan adalah model Springate, Zmijewski, Altman dan terakhir Grover. Terlihat juga output test statistic pada tabel diatas dimana jumlah sample 80, nilai Chi Squre hitung sebesar 52.299, df (derajat kebebasan) sebesar 3 dan asymp sig 0.000 sehingga didapatkan nilai Chi Square Tabel adalah sebesar 7.815, karena nilai Chi Square Hitung > Chi Squre Tabel , maka Ho ditolak dan Ha diterima atau dengan kata lain ada perbedaan frekwensi status prediksi financial distress antara Altman, Springate, Zmijewski dan Grover.

Uji statistik Kendall's W pada tabel 4.20 diatas terlihat ranking status model financial distress yang menyatakan distress tertinggi secara berurutan adalah model Springate, Zmijewski, Altman dan terakhir Grover. Terlihat juga output test statistic pada tabel diatas dimana jumlah sample 80, nilai Chi Squre hitung sebesar 52.299, df 
(derajat kebebasan) sebesar 3 dan asymp sig 0.000 sehingga didapatkan nilai Chi Square Tabel adalah sebesar 7.815, karena nilai Chi Square Hitung > Chi Squre Tabel , maka Ho ditolak dan Ha diterima atau dengan kata lain ada ada perbedaan ranking rata-rata status model financial distress pada keempat kelompok waktu pengukuran.

Dari hasil pengujian hipotesis yang telah dilakukan, menyatakan ada hipotesis yang diterima dan ada juga hipotesis yang ditolak. Hipotesis untuk menguji tingkat kelayakan model prediksi financial distress jika digunakan pada perusahaan di Indonesia.

Pengujian pertama bertujuan untuk mengetahui apakah Model Altman bisa digunakan untuk memprediksi financial distress pada perusahaan jasa studi kasus (sub sektor investasi dan sekuritas) yang terdaftar di bursa efek Indonesia.

Hasil pengujian pada hipotesis pertama menunjukkan bahwa model Altman mampu memprediksi financial distress dengan cukup baik. Dari 4 variabel yang digunakan (WCTA,RETA, EBITTA, MVETL), 3 variabel yang berpengaruh signifikan yaitu WCTA, RETA dan EBITTA. Variabel WCTA, RETA dan EBITTA menunjukkan mampu memprediksi financial distress perusahaan. Sementara variabel MVETL menunjukkan tidak mampu memprediksi financial distress perusahaan. Hasil ini menekankan bagi para investor dan stakeholder bahwa rasio WCTA, RETA dan EBITTA bisa menjadi patokan untuk menganalisis going concern perusahaan dengan melakukan prediksi financial distres. Dari hasil penelitian ini model Altman dinilai layak untuk digunakan di Indonesia sebagai alat dalam memprediksi financial distress.

Pengujian kedua bertujuan untuk mengetahui apakah Model Springate bisa digunakan untuk memprediksi financial distress pada perusahaan jasa studi kasus (sub sektor investasi dan sekuritas) yang terdaftar di bursa efek Indonesia .

Hasil pengujian pada hipotesis kedua menunjukkan bahwa model Springate mampu memprediksi financial distress dengan cukup baik. Dari 4 variabel yang digunakan (WCTA,RETA, EBTCL, STA) , 3 variabel yang berpengaruh signifikan yaitu WCTA, RETA dan EBTCL. Variabel WCTA, RETA dan EBTCL menunjukkan mampu memprediksi financial distress perusahaan. Sementara variabel STA menunjukkan tidak mampu memprediksi financial distress perusahaan. Hasil ini menekankan bagi para investor dan stakeholder bahwa rasio WCTA, RETA dan EBTCL bisa menjadi patokan untuk menganalisis going concern perusahaan dengan melakukan prediksi financial distres. Dari hasil penelitian ini model Springate dinilai layak untuk digunakan di Indonesia sebagai alat dalam memprediksi financial distress.

Pengujian ketiga bertujuan untuk mengetahui apakah Model Zmijewski bisa digunakan untuk memprediksi financial distress pada perusahaan jasa studi kasus (sub sektor investasi dan sekuritas) yang terdaftar di bursa efek Indonesia .

Hasil pengujian pada hipotesis kedua menunjukkan bahwa model Zmijewski mampu memprediksi financial distress dengan cukup baik. Dari 3 variabel yang digunakan (NITA, DAR, CR) , 2 variabel yang berpengaruh signifikan yaitu NITA dan DAR. Variabel NITA dan DAR menunjukkan mampu memprediksi financial distress perusahaan. Sementara variabel CR menunjukkan tidak mampu memprediksi financial 
distress perusahaan. Hasil ini menekankan bagi para investor dan stakeholder bahwa rasio NITA dan DAR dapat menjadi patokan untuk menganalisis going concern perusahaan dengan melakukan prediksi financial distres. Dari hasil penelitian ini model Zmijewski dinilai layak untuk digunakan di Indonesia sebagai alat dalam memprediksi financial distress.

Pengujian keempat bertujuan untuk mengetahui apakah Model Grover bisa digunakan untuk memprediksi financial distress pada perusahaan jasa studi kasus (sub sektor investasi dan sekuritas) yang terdaftar di bursa efek Indonesia. Hasil pengujian pada hipotesis kedua menunjukkan bahwa model Grover mampu memprediksi financial distress dengan cukup baik. Dari 3 variabel yang digunakan (WCTA, EBITTA, NITA), seluruh variabel yang berpengaruh signifikan. Variabel WCTA, EBITTA dan NITA menunjukkan mampu memprediksi financial distress perusahaan. Hasil ini menekankan bagi para investor dan stakeholder bahwa rasio WCTA, EBITTA dan NITA dapat menjadi patokan untuk menganalisis going concern perusahaan dengan melakukan prediksi financial distres.

Dari hasil penelitian ini model Grover dinilai layak untuk digunakan di Indonesia sebagai alat dalam memprediksi financial distress. Hasil penelitian ini sejalan dengan penelitian sebelumnya yang dilakukan oleh Yuniwati, dimana dalam penelitianya menyimpulkan bahwa model Grover dapat digunakan sebagai prediktor financial distress dengan menggunakan variabel WCTA.

Pengujian kelima bertujuan untuk mengetahui model prediksi financial distress terbaik digunakan dari empat model yang diteliti. Hasil pengujian pada hipotesis keempat menunjukkan bahwa model Grover merupakan model yang terbaik didukung dengan seluruh variabel yang berpengaruh signifikan. Sementara model Altman, Springate dan Zmijewski dinilai kurang sempurna karena dianggap tidak semua variabelnya mampu memprediksi financial distress pada perusahaan jasa studi kasus (sub sektor investasi dan sekuritas) yang terdaftar di Bursa Efek Indonesia karena terdapat satu variabel independennya yang tidak berpengaruh signifikan dalam memprediksi financial distress.

Model Altman jika digunakan di Indonesia, ternyata dari 4 variabel yang dianggap mampu menjadi faktor penentu prediksi financial distress pada perusahaan jasa studi kasus (sub sektor investasi dan sekuritas) yang terdaftar di Bursa Efek Indonesia, hanya 3 variabel yang berpengaruh positif terhadap financial distress, yaitu WCTA, RETA dan EBITTA sementara MVETL tidak berpengaruh positif.

Model Springate jika digunakan di Indonesia, ternyata dari 4 variabel yang dianggap mampu menjadi faktor penentu prediksi financial distress pada perusahaan jasa studi kasus (sub sektor investasi dan sekuritas) yang terdaftar di Bursa Efek Indonesia, hanya 3 variabel yang berpengaruh positif terhadap financial distress, yaitu WCTA, RETA dan EBTCL sementara STA tidak berpengaruh positif.

Model Zmijewski jika digunakan di Indonesia, ternyata dari 3 variabel yang dianggap mampu menjadi faktor penentu prediksi financial distress pada perusahaan jasa studi kasus (sub sektor investasi dan sekuritas) yang terdaftar di Bursa Efek 
Indonesia, hanya 2 variabel yang berpengaruh positif terhadap financial distress yaitu NITA dan DAR sedangkan CR tidak berpengaruh positif.

\section{Kesimpulan}

Model Grover jika digunakan di Indonesia, ternyata dari 3 variabel yang dianggap mampu menjadi faktor penentu prediksi financial distress pada perusahaan jasa studi kasus (sub sektor investasi dan sekuritas) yang terdaftar di Bursa Efek Indonesia, semua variabel berpengaruh positif terhadap financial distress yaitu WCTA, EBITTA dan NITA.

Dari keempat model prediksi financial distress yang diteliti model Grover terbaik, kemampuan variabel independen secara bersama-sama dalam memprengaruhi variabel dependen juga cukup baik, dari 3 variabel yang digunakan, semua variabel berpengaruh positif terhadap financial distress. Model Grover juga yang paling rendah memprediksi perusahaan yang distress baik melalui uji deskriptif crosstab maupun non parametrik sesuai dengan kondisi real yang ada dimana perusahaan jasa studi kasus (sub sektor investasi dan sekuritas) yang terdaftar di Bursa Efek Indonesia yang dijadikan sample penelitian tersebut sampai dengan tahun 2016 tidak ada yang distress dan baru pada tahun 2018 ada 1 (satu) perusahaan yang di suspend. 
Pertarungan Model Altman, Springate, Zmijewski dan Grover Memprediksi Financial Distress Perusahaan Jasa

\section{Bibliografi}

Adnan, Hafiz, \& Arisudhana, Dicky. (2017). Analisis kebangkrutan model Altman ZScore dan Springate pada perusahaan industri property. Jurnal Akuntansi Dan Keuangan, 1(1).

Aprillianto, Bayu, Wulandari, Novi, \& Kurrohman, Taufik. (2014). Perilaku investor saham individual dalam pengambilan keputusan investasi: Studi HermeneutikaKritis. E-Journal Ekonomi Bisnis Dan Akuntansi, 1(1), 16-31.

Armini, Ni Nyoman Ayu, \& Wirama, Dewa Gede. (2015). Pengaruh Pertumbuhan Perusahaan, Kepemilikan Manajerial dan Kebijakan Dividen pada Kinerja Perusahaan. E-Jurnal Akuntansi, 12(2), 313-327.

Chrisnawan, Rico, \& Norita, Norita. (2017). Analisis Prediksi Kebangkrutan Menggunakan Metode Altman Z-score, Grover Dan Fulmer Pada Industri Sub Sektor Perkebunan Yang Terdaftar Di Bursa Efek Indonesia (studi Kasus Perusahaan Perkebunan Kelapa Sawit Periode 2011-2015). EProceedings of Management, 4(1).

Fatmawati, Mila. (2012). Penggunaan the Zmijewski Model, the Altman Model, dan the Springate Model sebagai prediktor delisting. Jurnal Keuangan Dan Perbankan, 16(1).

HARTONO, ULIL. (2014). UJI PENERAPAN MODEL PREDIKSI FINANCIAL DISTRESS ALTMAN, SPRINGATE, OHLSON DAN ZMIJEWSKI PADA PERUSAHAAN SEKTOR KEUANGAN DI BURSA EFEK INDONESIA APRILIA SAFITRI. Jurnal Ilmu Manajemen| Volume, 2(2).

KARTIKA, TITIS PUSPITANINGRUM DEWI, \& Purnamasari, Linda. (2016). Analisis Prediktor Delisting Terbaik (Perbandingan Antara Model Zmijewski, Model Altman, Model Springate). Jurnal Buletin Studi Ekonomi, 21(1), 38-47.

Kusdiana, Yayu. (2014). Analisis Model CAMEL dan Altman's Z-Score dalam Memprediksi Kebangkrutan Bank Umum di Indonesia (Studi pada Bank Umum yang Tercatat di Bursa Efek Indonesia Tahun 2007-2011). Jurnal Tepak Manajemen Bisnis, 6(1).

Marcelinda, Sheilly Olivia. (2014). Analisis Akurasi Prediksi Kebangkrutan Model Altman Z-Score pada Perusahaan Manufaktur yang Terdaftar di Bursa Efek Indonesia. E-Journal Ekonomi Bisnis Dan Akuntansi, 1(1), 1-3.

Prihanthini, Ni Made Evi Dwi, \& Sari, Maria M. Ratna. (2013). Prediksi Kebangkrutan Dengan Model Grover, Altman Z-Score, Springate Dan Zmijewski Pada Perusahaan Food And Beverage Di Bursa Efek Indonesia. E-Jurnal Akuntansi Universitas Udayana, 5(2), 417-435.

Purnajaya, Komang Devi Methili, \& Merkusiwati, NKLA. (2014). Analisis Komparasi 
Mohamad Ismail Chandra' ${ }^{1}$, Suyanto², Tri Widyastuti ${ }^{3}$, Nurmala Ahmar ${ }^{4}$

Potensi Kebangkrutan Dengan Metode Z-Score Altman, Springate, Dan Zmijewski Pada Industri Kosmetik Yang Terdaftar Di Bursa Efek Indonesia. E-Jurnal Akuntansi Universitas Udayana, 7(1), 48-63.

Ramadhani, Ayu Suci, \& Lukviarman, Niki. (2009). Perbandingan analisis prediksi kebangkrutan menggunakan Model Altman pertama, Altman revisi, dan altman modifikasi dengan ukuran dan umur perusahaan sebagai variabel penjelas (studi pada perusahaan manufaktur yang terdaftar di Bursa Efek Indonesia). Jurnal Siasat Bisnis, 13(1).

Rudianto, Edi. (2013). Akuntansi Manajemen Informasi Untuk Pengambilan Keputusan Strategis. Jakarta: Erlangga.

Sayyidah, Ulfah, \& Saifi, Muhammad. (2017). Pengaruh Intellectual Capital Terhadap Nilai Perusahaan Dengan Profitabilitas Sebagai Variabel Moderasi (Studi Pada Perusahaan Sub Sektor Property Dan Real Estate Di Bursa Efek Indonesia Periode 2013-2015). Jurnal Administrasi Bisnis, 46(1), 163-171.

Van Horne, James C., \& Wachowicz, John M. (2021). Prinsip-prinsip manajemen keuangan.

Wulandari, Tessa Fitria. (n.d.). PENGARUH LIKUIDITAS, PROFITABILITAS, UKURAN PERUSAHAAN, DAN PERTUMBUHAN PENJUALAN TERHADAP STRUKTUR MODAL. 